\title{
High Tolerant and Durable Adhesion between Hydrogels Utilizing Intercalation of Cationic Substituents into Layered Inorganic Compound.
}

\author{
Shingo Tamesue, ${ }^{\dagger, \ddagger}$ Kento Yasuda, $^{\dagger}$ Shingo Noguchi, ${ }^{\dagger}$ Tetsu Mitsumata, ${ }^{\dagger, \ddagger}$ Takeshi \\ Yamauchi $^{\dagger, \ddagger}$
}

${ }^{\dagger}$ Graduate School of Science and Technology, Niigata University, Nishi-ku Ikarashi-2-8050, Niigata, Japan.

${ }^{\ddagger}$ Faculty of Engineering, Niigata University, Nishi-ku lkarashi-2-8050, Niigata, Japan.

1. General.

1-Methylimidazole and 4-chloromethylstyrene were purchased from Wako Pure Chemicals Co., Inc. $\mathrm{pH}=1.68$ (Oxalate) and $13.0(\mathrm{KOH} / \mathrm{NaOH})$ buffer solutions were purchased from Kanto Chemical Co., Inc, and Tokyo Chemical Industry Co., LTD, respectively. All other chemicals were purchased from KANTO Chemical Co., Inc. and used as received. All solvents utilized in this research were reagent grade $(99.9 \%)$. Aqueous dispersion of Micromica (MEB-3, diameter is 2.0-3.0 $\mu \mathrm{m}$ ) was provided from Katakura \& Co-op Agri Corporation. Laponite (Laponite-RD) was provided from ALTANA Corporation. ${ }^{1} \mathrm{H}$ NMR spectra were recorded on a Varian model 400-MR spectrometer. ${ }^{13} \mathrm{C}$ NMR spectra were recorded on a Varian model NMR System 700 spectrometer. ESI-Ms spectra were collected on a mass spectrometer (Water/Micromass, ZQ-4000). 90 degree peeling test and shear adhesive strength were carried out using Imada MX2-500N-FA equipped with Imada, ZTA-50N. The rate of extending samples was $10 \mathrm{~mm} / \mathrm{sec}$. Attenuated total reflection infrared (ATR-IR) spectroscopy was conducted by using Shimadzu FTIR-8400S. Rheology data was measured by using Anton-Paar, MCR-301 with a $25 \mathrm{~mm}$ diameter parallel plate attached to a transducer. The gap was set at $1.0 \mathrm{~mm}$. Thermogravimetric analysis (TGA) was conducted by using Shimadzu Manufacturing Co., Ltd. TGA-50. X-ray diffraction (XRD) patterns were obtained using Bruker, D2 Phaser. High concentration hydrogels shown in Figure 5 in the manuscript and in Figure S5 were prepared by evaporating water of the hydrogel prepared in session 3-1 in the air. 
2. Synthesis of imidazolium monomer (ImM).

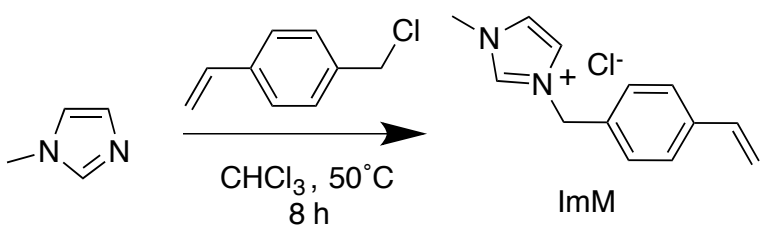

Imidazolium monomer $(\mathrm{ImM})$ was synthesized according to the literature other researcher previously reported. $^{\mathrm{S1}}$

1-Methylimidazol (1.59 mL, $20.0 \mathrm{mmol})$ and 4-chloromethylstyrene $(3.52 \mathrm{~mL}, 25.0 \mathrm{mmol})$ was dissolved into $10 \mathrm{~mL}$ of acetonitrile and heated at $50^{\circ} \mathrm{C}$ for 8 hours. After cooled to room temperature, the solvent was evaporated, and extracted with water and ethylacetate. After extraction, aqueous layer was collected and the solvent was evaporated. Finally, clear oil was obtained as ImM. Yield: $4.66 \mathrm{~g}, 99 \%$. ${ }^{1} \mathrm{H}$ NMR ( $\mathrm{D}_{2} \mathrm{O}$, r.t.): $\delta 3.82$ (s, 3H), $5.30(\mathrm{~d}, 1 \mathrm{H}), 5.31(\mathrm{~s}, 2 \mathrm{H})$, $5.83(\mathrm{~d}, 1 \mathrm{H}), 6.73-6.77(\mathrm{~m}, 1 \mathrm{H}), 7.33(\mathrm{~d}, 2 \mathrm{H}), 7.39(\mathrm{~d}, 2 \mathrm{H}), 7.50(\mathrm{~d}, 2 \mathrm{H}), 8.69(\mathrm{~s}, 1 \mathrm{H}) .{ }^{13} \mathrm{C}$ NMR $\left(\mathrm{CDCl}_{3}\right.$, r.t.): $\delta 36.7,53.0,115.5,121.7,123.4,127.1,129.3,132.4,135.8,138.7 . \mathrm{MS}$ (ESI): calcd for $\mathrm{C}_{13} \mathrm{H}_{15} \mathrm{~N}_{2}[\mathrm{M}]^{+}: \mathrm{m} / \mathrm{z}=199.1$, found: 199.2 .

(S1) W. Chen, Y. Zhang, L. Zhu, J. Lan, R. Xie, J. You, J. Am. Chem. Soc., 2007, 129, 13879.

3. Preparation of hydrogels.

3-1. Preparation of cationic hydrogel.
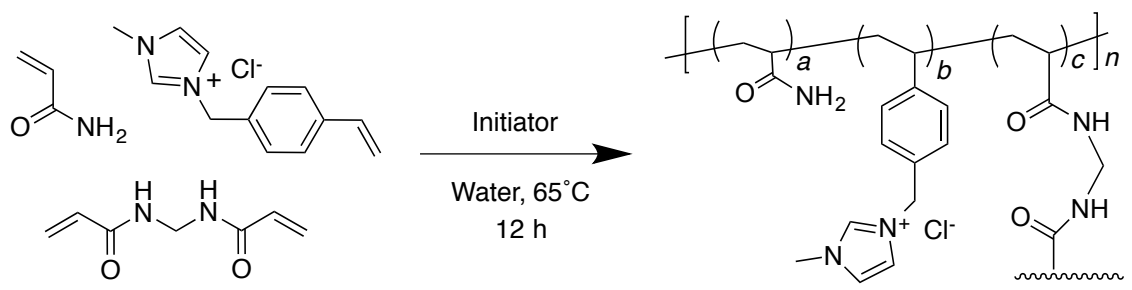

Acrylamide (AAm, $2.13 \mathrm{~g}, 30.0 \mathrm{mmol}$ ), N,N'-methylenebisacrylamide (MBAm, $4.62 \mathrm{mg}, 3.00 \times$ $\left.10^{-2} \mathrm{mmol}\right)$ and ImM (46.9 mg, $\left.2.00 \times 10^{-1} \mathrm{mmol}\right)$ were dissolved in $10 \mathrm{~mL}$ of water. After $\mathrm{N}_{2}$ bubbling for 1 hour, 2,2'-azobis[2-(2-imidazolin-2-yl)propane] (ABIP, $5.01 \mathrm{mg}, 2.00 \times 10^{-1} \mathrm{mmol}$ ) was added as a radical initiator, and the solution was heated at $65^{\circ} \mathrm{C}$ for 12 hour. Finally, clear hydrogel was obtained. 
3-2. Preparation of non-ionic hydrogel (Neutral hydrogel).

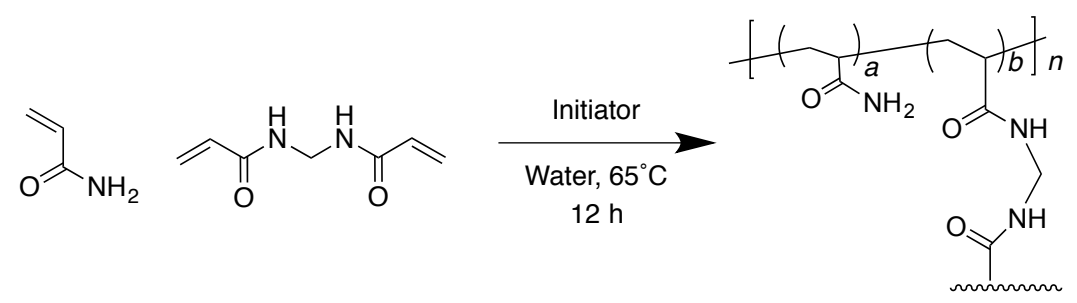

AAm $(2.13 \mathrm{~g}, 30.0 \mathrm{mmol})$ and MBAm $\left(4.62 \mathrm{mg}, 3.00 \times 10^{-2} \mathrm{mmol}\right)$ were dissolved in $10 \mathrm{~mL}$ of water. After $\mathrm{N}_{2}$ bubbling for 1 hour, ABIP $\left(5.01 \mathrm{mg}, 2.00 \times 10^{-1} \mathrm{mmol}\right)$ was added as a radical initiator, and the solution was heated at $65^{\circ} \mathrm{C}$ for 12 hour. Finally, clear hydrogel was obtained. 


\section{Reference adhering experiments.}

To investigate the interaction cross-linking cationic hydrogels, reference adhering experiments were carried out as shown in Figure S1. Also, the summary of the adhesion experiments was shown in Table S1.
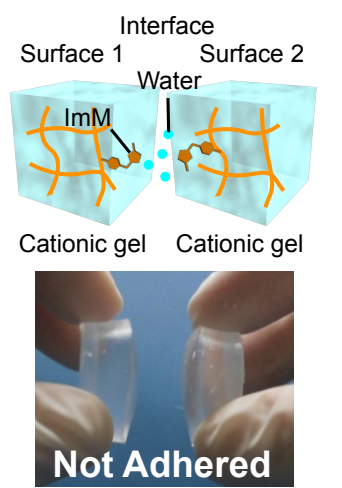

Cationic hydrogels Water
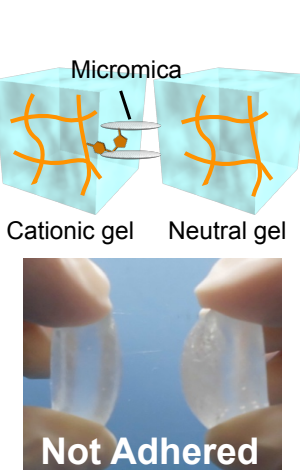

Cationic / Neutral hydrogels Micromica
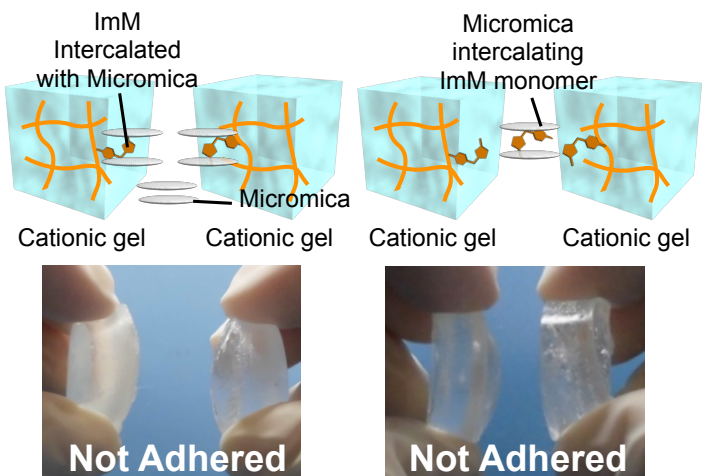

Intercalated cationic hydrogels Micromica

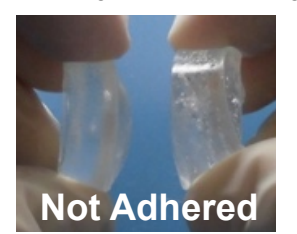

Cationic hydrogels Intercalating Micromica

Figure S1. Photographs of cationic gels treated with water $(40 \mu \mathrm{L})$ instead of Micromica, cationic gel and neutral AAm gel treated with Micromica ( $40 \mu \mathrm{L}, 4.0 \mathrm{wt} \%)$, cationic hydrogels in which ImM groups were intercalated into Micromica in advance using Micromica (40 $\mu \mathrm{L}, 4.0 \mathrm{wt} \%$ ) and cationic gels using Micromica ( $40 \mu \mathrm{L}, 4.0 \mathrm{wt} \%)$ in which ImM was intercalated in advance.

Table S1. Summary of the adhesion experiments.

\begin{tabular}{lllll}
\hline Sample Name & Surface 1 & Surface 2 & Interface & Adhesive ability \\
\hline $\begin{array}{c}\text { Cationic hydrogels } \\
\text { Micromica }\end{array}$ & Cationic & Cationic & Micromica & Strong \\
\hline $\begin{array}{c}\text { Cationic hydrogels } \\
\text { Water }\end{array}$ & Cationic & Cationic & Water & None \\
\hline $\begin{array}{c}\text { Cationic / Neutral } \\
\text { hydrogels } \\
\text { Micromica }\end{array}$ & Cationic & Neutral & Micromica & None \\
\hline $\begin{array}{c}\text { Intercalated } \\
\text { cationic hydrogels } \\
\text { Micromica }\end{array}$ & $\begin{array}{c}\text { Cationic, but } \\
\text { intercalated with } \\
\text { Micormica }\end{array}$ & $\begin{array}{c}\text { Cationic, but } \\
\text { intercalated with } \\
\text { Micormica }\end{array}$ & Micromica & None \\
\hline $\begin{array}{c}\text { Cationic hydrogels } \\
\text { Intercalating } \\
\text { Micromica }\end{array}$ & Cationic & Cationic & $\begin{array}{c}\text { Micromica which } \\
\text { interlayer was filled } \\
\text { with ImM }\end{array}$ & None \\
\hline
\end{tabular}


5. Tolerance toward saturated saline solution, acidic, and basic solutions.

(a) Micromica

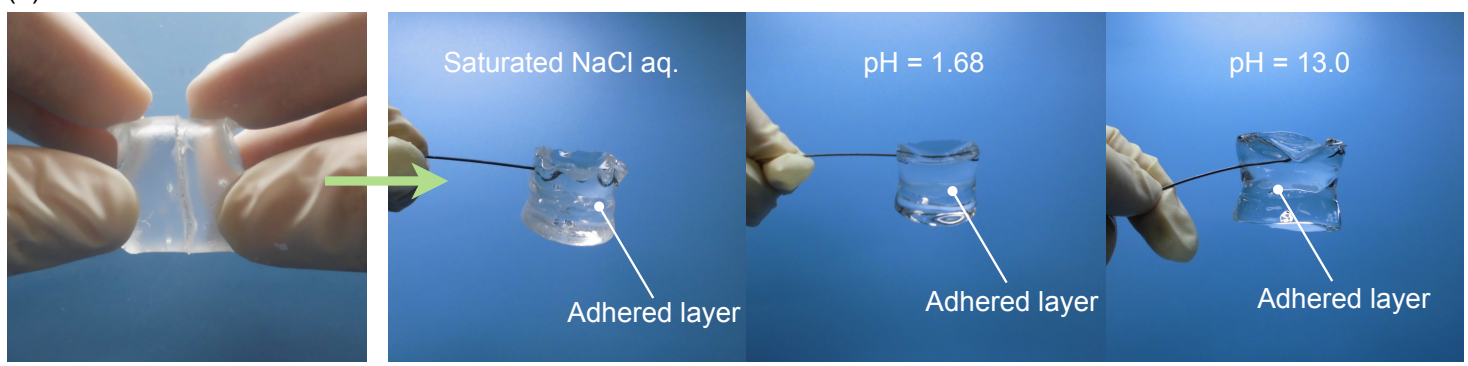

(b) Laponite

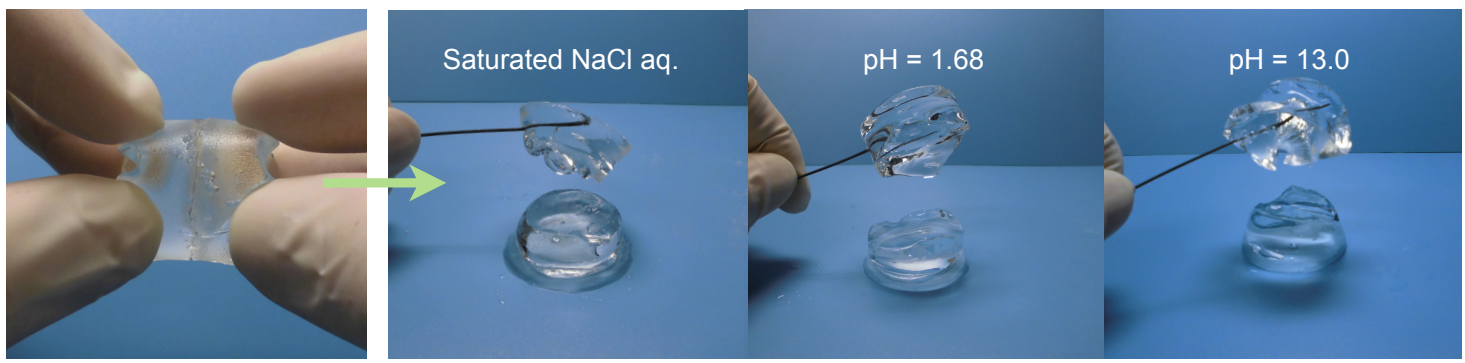

Figure S2. Photographs of cationic hydrogels $\left([\mathrm{ImM}]=20.0 \mathrm{mM},[\mathrm{AAm}]=3.00 \times 10^{3} \mathrm{mM}\right.$, and $[M B A m]=3.00 \mathrm{mM})$ adhered with Micromica or Laponite $(4.0 \mathrm{wt} \%, 40 \mu \mathrm{L})$ before and after immersion into saturated saline solution, acidic $(\mathrm{pH}=1.68)$, and basic $(\mathrm{pH}=13.0)$ solutions for 24 hours.

6. Molecular length of intercalated Micromica.

Interlayer distance calculated from XRD pattern, and molecular length of Micromica and ImM are shown in Figure S3.

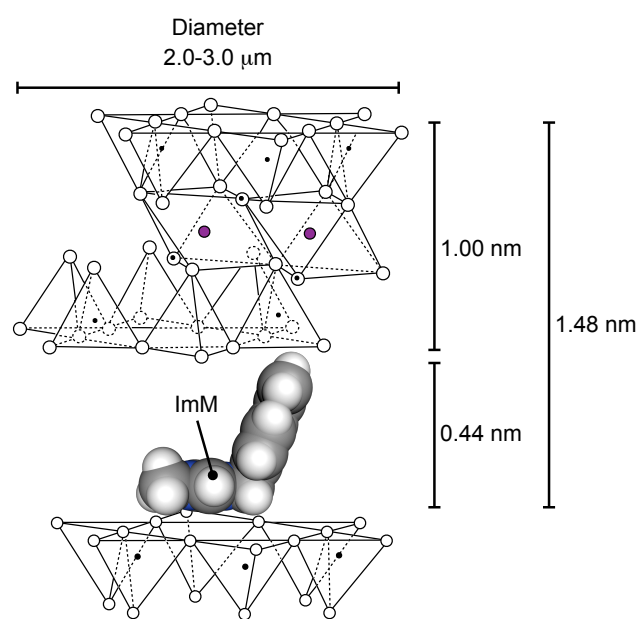

Figure S3. Schematic illustration and molecular length of Micromica and ImM. 
7. 90 degree peeling test.

To investigate the adhesive strength of hydrogels, 90 degree peeling test was carried out as shown in Figure S4. The shapes of hydrogels utilized in the peeling test were shown in Figure 3a.
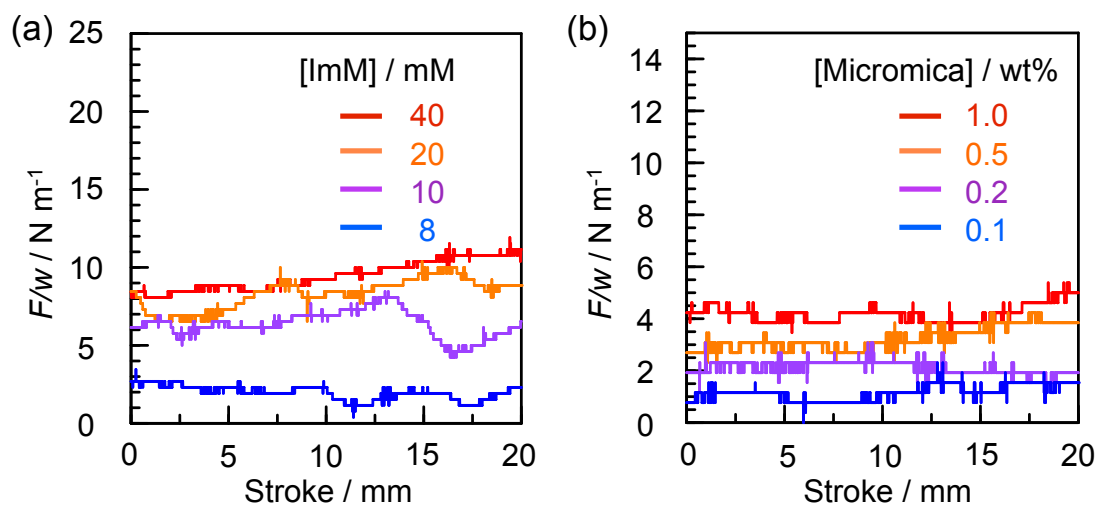

Figure S4. 90 degree peeling test data of (a) hydrogels having respective ImM concentrations $\left([\mathrm{ImM}]=8.0-40.0 \mathrm{mM},[\mathrm{AAm}]=3.00 \times 10^{3} \mathrm{mM}\right.$, and $\left.[\mathrm{MBAm}]=3.00 \mathrm{mM}\right)$ treated with Micromica $(4.0 \mathrm{wt} \%, 150 \mu \mathrm{L})$, and $(\mathrm{b})$ hydrogels $\left([\mathrm{ImM}]=20.0 \mathrm{mM},[\mathrm{AAm}]=3.00 \times 10^{3} \mathrm{mM}\right.$, and [MBAm] $=$ $3.00 \mathrm{mM})$ treated with respective concentrations of Micromica $(0.1-1.0 \mathrm{wt} \%, 100 \mu \mathrm{L})$. 
8. Shape of hydrogels for shear adhesive strength measurement.

Shape of the hydrogels for tensile test was shown in Figure S5. Two pieces of hydrogels were put together after applied an aqueous dispersion of Micromica onto the surface of hydrogel.

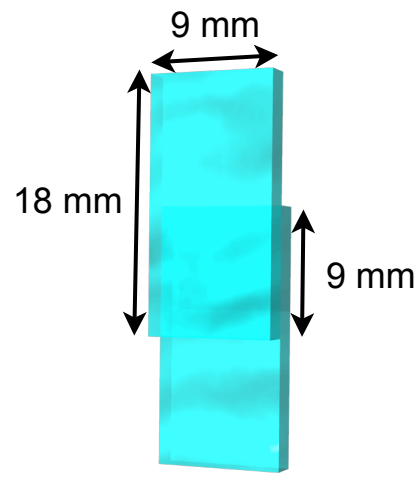

Figure S5. Shape of adhered hydrogels for shear adhesive strength measurement.

9. Time-course change of shear adhesive strength working between hydrogels.

To evaluate the adhesive force depending on adhesive time, shear adhesive strength of hydrogels adhered for respective time was measured as shown in Figure S6.
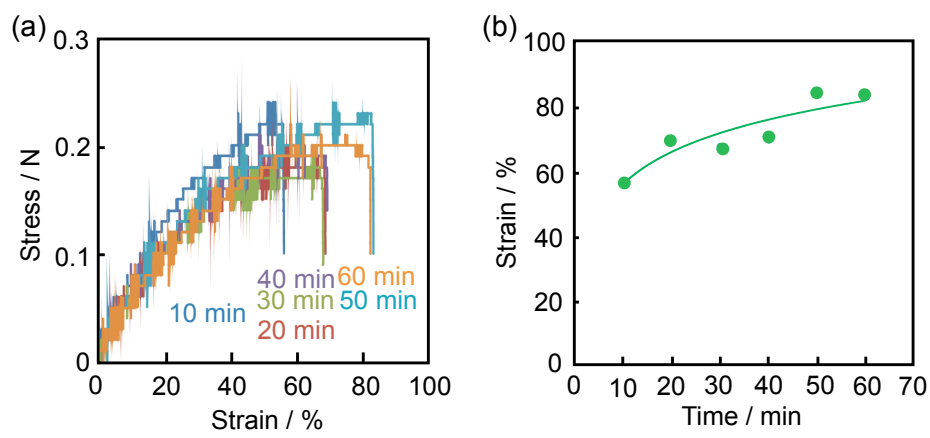

Figure S6. (a) Time-course changes of strain-stress curves obtained from hydrogels formed from AAm $\left(3.00 \times 10^{3} \mathrm{mM}\right), \mathrm{MBAm}(3.00 \mathrm{mM})$ and ImM (20.0 mM) after adhered with Micromica (4.0 wt\%), and (b) time-course changes of maximum strain of the adhered hydrogels. 
10. Rheological measurement.

To evaluate the concentration dependency of cationic substituents or Micromica on G' and G" values of polymer networks, rheological measurement was carried out as shown in Figure S7. Aqueous mixtures of AAm $\left(8.33 \times 10^{2} \mathrm{mM}\right)$ and respective concentration of ImM ( 0 to $\left.16.7 \mathrm{mM}\right)$ were polymerized utilizing ABIP $(1.67 \mathrm{mM})$ as a radical initiator, and aqueous dispersion of Micromica $\left(6.67 \times 10^{-1} \mathrm{wt} \%\right)$ was added to the solution. After preparation, G' and G' of the aqueous mixtures were measured as shown in Figure S7a. Also, the G' and G' of aqueous mixtures of AAm and ImM were polymerized and mixed with respective concentration of Micromica $\left(8.33 \times 10^{-2}\right.$ to $\left.6.67 \times 10^{-1} \mathrm{wt} \%\right)$ were measured and shown in Figure S7b. As can be seen in Figure S7a and S7b, the G' values increased as the values of the aqueous mixture without ImM or Micromica did not increase significantly as shown in Figure S7c and S7d.
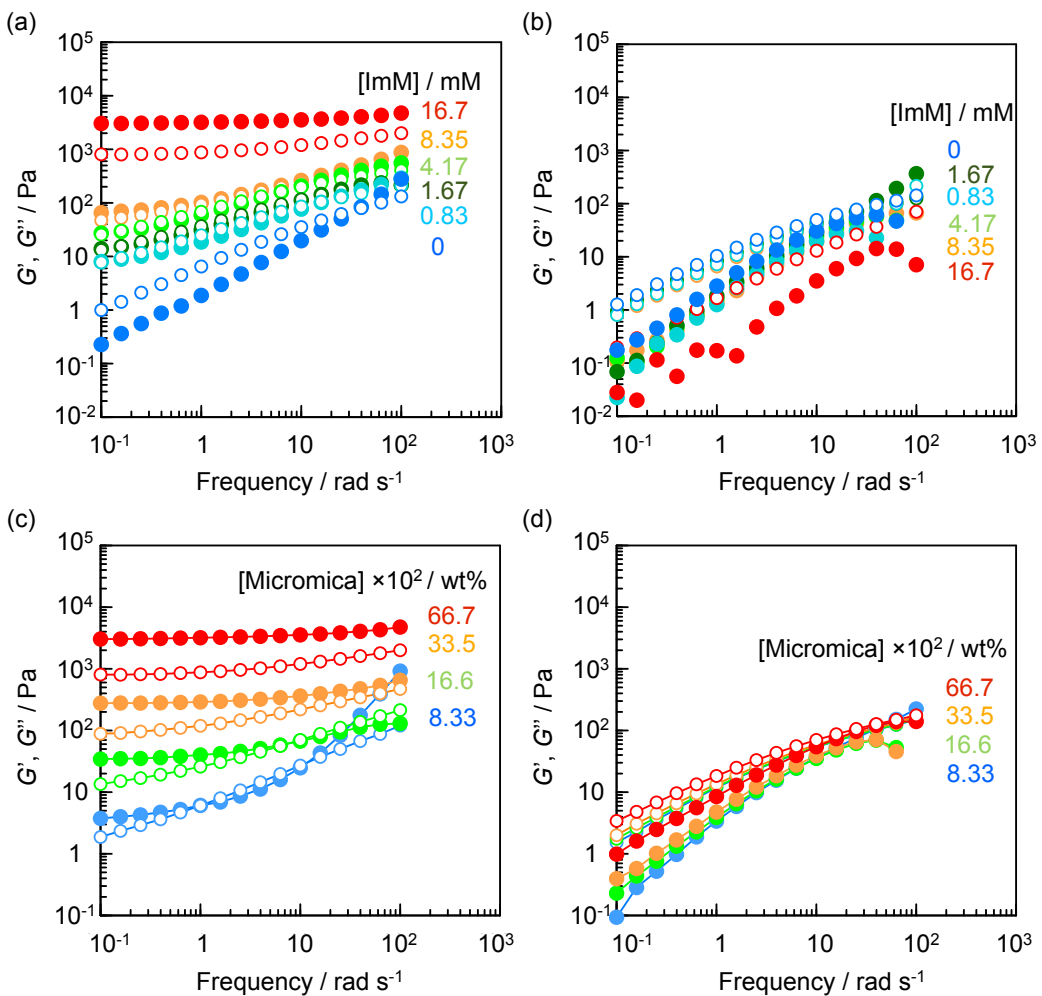

Figure S7. G' (close circles) and G" (open circles) values $\left(\omega=10^{-1}\right.$ to $10^{2} \mathrm{rad} \mathrm{s}^{-1}$ and strain $(\gamma)=$ $0.5 \%)$ of (a) a polymerized mixtures of $\operatorname{ImM}(0$ to $16.7 \mathrm{mM})$ and $\mathrm{AAm}\left(8.33 \times 10^{2} \mathrm{mM}\right)(\mathrm{a})$ with or (b) without Micromica $\left(6.67 \times 10^{-1} \mathrm{wt} \%\right)$, and a dispersion of AAm $\left(8.33 \times 10^{2} \mathrm{mM}\right)$ polymerized (c) with or (d) without ImM (16.7 mM) after the addition of various concentrations of Micromica $\left(8.33 \times 10^{-2}\right.$ to $\left.6.67 \times 10^{-1} \mathrm{wt} \%\right)$. 
11. Dependency of shear adhesion strength on the water content ratio.

Strain-stress curves of adhered hydrogels with respective water content ratios were shown in Figure S8.

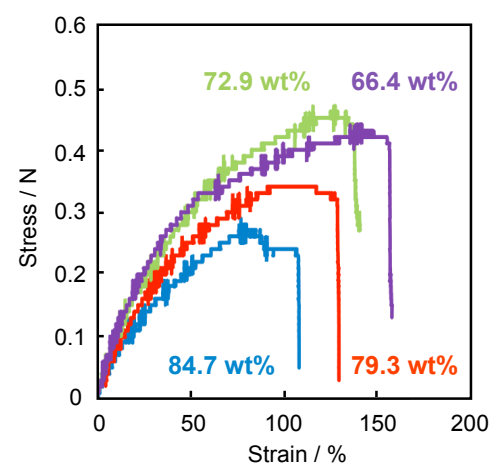

Figure S8. Strain-stress curves of adhered hydrogels with respect water content ratios (66.4 $84.7 \mathrm{wt} \%)$.

12. Wide range photographs of adhered cationic hydrogels lifting up $10 \mathrm{~kg}$ of weight.

Figure S9 shows the wide range photographs of the experiment lifting up $10 \mathrm{~kg}$ of weight.

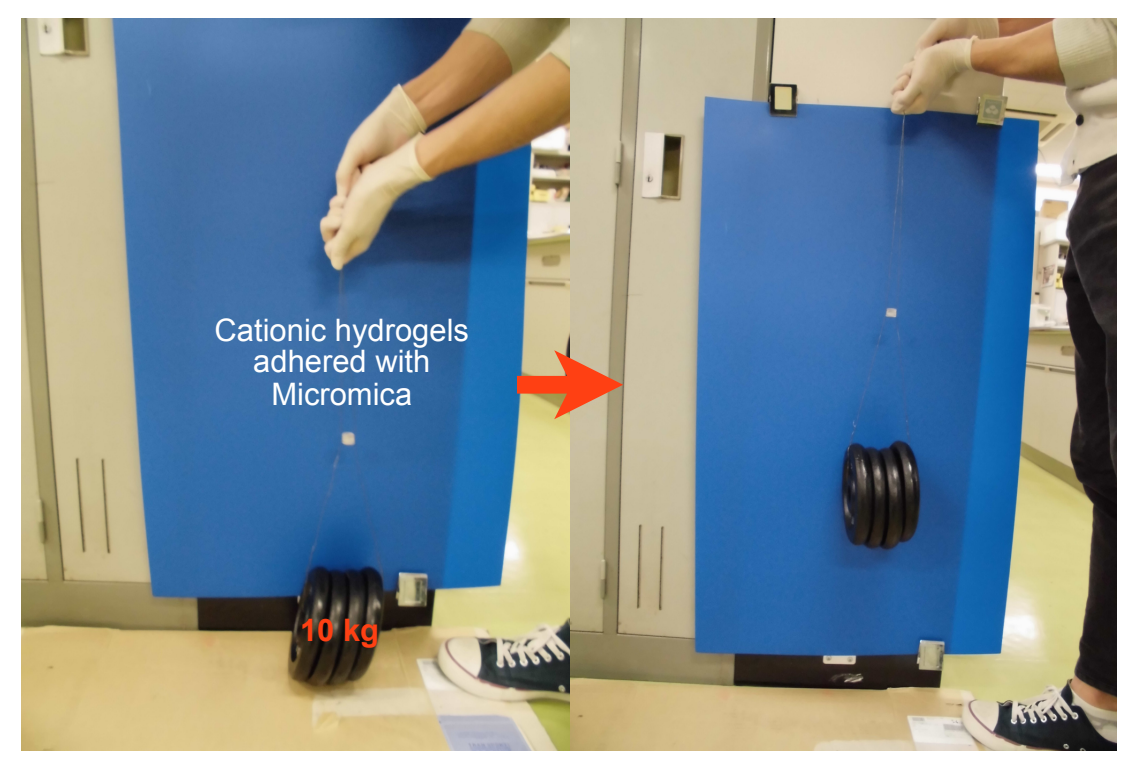

Figure S9. Photographs of cationic hydrogels adhered with $1.6 \mathrm{mg}$ of Micromica before (left) and after (right) lifting up $10 \mathrm{~kg}$ of weight. 